\title{
Ursolic acid elicits intrinsic apoptotic machinery by downregulating the phosphorylation of AKT/BAD signaling in human cisplatin-resistant oral cancer CAR cells
}

\author{
CHIN-FU CHEN ${ }^{1}$, JAI-SING YANG ${ }^{2}$, WEN-KANG CHEN ${ }^{3}$, CHI-CHENG LU $^{4}$, JO-HUA CHIANG ${ }^{5}$, \\ HONG-YI CHIU ${ }^{4,6,7}$, SHIH-CHANG TSAI ${ }^{8}$, YU-NING JUAN ${ }^{2}$, \\ HAO-JEN HUANG ${ }^{1,9}$ and TZONG-DER WAY ${ }^{8}$
}

\begin{abstract}
${ }^{1}$ Department of Life Sciences, National Cheng Kung University, Tainan 70101; ${ }^{2}$ Department of Medical Research, China Medical University Hospital, China Medical University, Taichung 40447; ${ }^{3}$ Department of Applied Cosmetology, National Tainan Junior College of Nursing, Tainan 70043; ${ }^{4}$ Department of Pharmacy, Buddhist Tzu Chi General Hospital, Hualien 97002; ${ }^{5}$ Department of Nursing, Chung Jen Catholic Junior College, Chiayi 62241; ${ }^{6}$ Master and PhD Program in Pharmacology and Toxicology, School of Medicine, Tzu Chi University, Hualien 97004; ${ }^{7}$ General Education Center, Tzu Chi University of Science and Technology, Hualien 97005; ${ }^{8}$ Department of Biological Science and Technology,

College of Biopharmaceutical and Food Sciences, China Medical University, Taichung 40402;

${ }^{9}$ Institute of Tropical Plant Sciences, National Cheng Kung University, Tainan 70101, Taiwan, R.O.C.
\end{abstract}

Received February 13, 2018; Accepted June 15, 2018

DOI: $10.3892 /$ or.2018.6530

\begin{abstract}
Oral squamous cell carcinoma (OSCC) is a type of cancer with high morbidity and mortality rates worldwide; it also demonstrates chemotherapeutic resistance. Triterpenoid ursolic acid has been shown to exhibit various biological activities and anticancer effects in several preclinical studies. In our previous study, human cisplatin-resistant oral cancer CAR cells were established, and the present study aimed to further examine the effects of ursolic acid on CAR cells. The results revealed that ursolic acid inhibited CAR cell viability, as determined using a 3-(4,5-dimethylthiazol-2-yl)-2,5-diphenyltetrazolium bromide assay. Ursolic acid-induced cell death was mediated through a caspase-dependent pathway, determined with the pan-caspase inhibitor, z-VAD-fmk. Ursolic acid also increased the activities of caspase- 3 and
\end{abstract}

Correspondence to: Dr Hao-Jen Huang, Department of Life Sciences, National Cheng Kung University, 1 University Road, Tainan 70101, Taiwan, R.O.C.

E-mail: haojen@mail.ncku.edu.tw

Dr Tzong-Der Way, Department of Biological Science and Technology, College of Biopharmaceutical and Food Sciences, China Medical University, 91 Hsueh-Shih Road, Taichung 40402, Taiwan, R.O.C.

E-mail:tdway@mail.cmu.edu.tw

Key words: ursolic acid, apoptosis, AKT/B-cell lymphoma-2associated agonist of cell death signaling, human cisplatin-resistant oral cancer CAR cells caspase-9 in CAR cells, determined by a colorimetric assay. Specifically, the production of reactive oxygen species and loss of mitochondrial membrane potential, detected by flow cytometry, were observed in the ursolic acid-treated CAR cells. The apoptosis-associated signaling showed that ursolic acid decreased the phosphorylation of AKT (Ser473) and B-cell lymphoma 2 (Bcl-2)-associated agonist of cell death (BAD; Ser136), and the protein levels of Bcl-2 and Bcl-extra large $(\mathrm{Bcl}-\mathrm{xL})$, and increased the expression of BAD and Bcl-2-associated X (Bax) protein in CAR cells. In summary, the results supported the potential application of ursolic acid against drug-resistant oral carcinoma and to improve oral anticancer efficacy in the near future.

\section{Introduction}

Oral squamous cell carcinoma (OSCC) is one of the most common types of head and neck cancer in the world and accounts for $\sim 95 \%$ of all cases of head and neck cancer $(1,2)$. Patients with OSCC have a five-year survival rate of $\sim 50 \%$, with the proportion of men with oral squamous cell carcinoma being higher than that of women $(2,3)$. The symptoms of OSCC include erythroplakia, leukoplakia, ulcers in the mouth, necrosis of the surface tissue, formation of an intermediate cavity or an uneven surface mass, bleeding, and swelling of the submandibular and cervical lymph nodes $(4,5)$. OSCC is mainly caused by chemical factors, including nicotine, alcohol and betel nut juice; physical factors, including the consumption of high-temperature foods over a long period; and viral infections, including human papillomavirus, Epstein-Barr virus and human immunodeficiency virus (6-8). Histologically, when a tumor has not invaded other organs in its formation, it can be classified via the symptoms of epithelial tissue 
according to reactive epithelial or pre-neoplasia preneoplastic changes $(9,10)$. The current chemotherapeutic agents for OSCC are cisplatin, 5-fluorouracil, bleomycin, mitomycin-c, methotrexate, oxaliplatin and tegafur/uracil $(11,12)$. Despite scientific investigations and advanced medical technological achievements, the prognosis of OSCC has remained poor over the last 10 years $(13,14)$. The focus of current investigations in novel drug identification is on the development of low-sideeffect and high-efficacy treatments against chemoresistant cancer cells.

Ursolic acid (3 $\beta$-hydroxy-urs-12-ene-28-oic acid) is a lipophilic and pentacyclic triterpenoid compound. The molecular weight of ursolic acid is $456.68 \mathrm{~g} / \mathrm{mole}$, and is a white powder that was first identified from the epicuticular wax of apples in 1920 (15). Ursolic acid is usually found in leaves, stem bark and fruit peel, and is present largely in specific plants and dietary foods, including basil, apples, peppermint, cranberries, rosemary, lavender, thyme, hawthorn, oregano, prunes, bilberries and elderflower (16-18). Ursolic acid has been used for its health-promoting activities via the composition of herb extracts applied in popular medicines for centuries (19-21). As ursolic acid exists in common edible plants, it is considered to exhibit almost no toxicity towards humans $(22,23)$. With the rapid developments in our understanding of traditional medicines, ursolic acid has been found to have pharmacological and biological effects, including antioxidant, anti-inflammatory, antidiabetic, antibacterial and antitumor activities. Furthermore, it is used in protection and prevention against cancer (19-23).

Ursolic acid may be a potential natural compound for cancer therapy (19-23). In previous years, ursolic acid has been found to possess pharmacological effects in the prevention and treatment of cancer $(24,25)$. The pharmacological activities of ursolic acid not only destroy cancer cells but also regulate cancer cell metabolism, prevent angiogenesis and metastasis, enhance cell differentiation, and protect healthy tissues from the oxidative and inflammatory stimulation that lead to the process of cancer cell metastasis (24-26). The present study aimed to examine the anti-growth effects of ursolic acid and the underlying mechanisms of apoptotic cell death in cisplatin-resistant human oral cancer CAR cells.

\section{Materials and methods}

Cell culture. The CAL 27 parental human oral cancer cell line was obtained from the American Type Culture Collection (ATCC, Manassas, VA, USA), which is a cell line identified as tongue squamous cell carcinoma. The cisplatin-resistant oral cancer CAR cells were established by gradient induction of increasing concentrations of cisplatin up to $80 \mu \mathrm{M}$ in CAL 27 cells, as previously described $(1,8,27)$. In brief, the CAL 27 cells were initially incubated with $10 \mu \mathrm{M}$ cisplatin for $24 \mathrm{~h}$, and the culture media was replaced by cisplatin-free fresh culture medium until the CAL 27 cells reached a confluence of $80-90 \%$. The procedure was repeated with increasing concentrations of cisplatin, and the CAL 27 cells were cultured with each concentration $(10-80 \mu \mathrm{M})$ of cisplatin for five cycles to obtain the cisplatin-resistant CAR cells. The CAR cells were cultured in Dulbecco's modified Eagle's medium (DMEM) with $10 \%$ fetal bovine serum (FBS), $2 \mathrm{mM}$ L-glutamine, $100 \mathrm{U} / \mathrm{ml}$ penicillin and $100 \mu \mathrm{g} / \mathrm{ml}$ streptomycin. Normal human primary gingival fibroblast (HGF) was obtained from CLS Cell Lines Service GmbH (Eppelheim, Germany) and cultivated in DMEM/F12 1:1 medium (HyClone Laboratories; GE Healthcare Life Sciences, Logan, UT, USA) supplemented with $10 \%$ FBS, $100 \mu \mathrm{g} / \mathrm{ml}$ streptomycin, $100 \mathrm{U} / \mathrm{ml}$ penicillin and $2 \mathrm{mM}$ L-glutamine. All cells were cultured in a $37^{\circ} \mathrm{C}$ humidified incubator with $5 \% \mathrm{CO}_{2}$.

Chemicals, reagents and antibodies. DMEM, DMEM/F12 1:1 medium, FBS, L-glutamine, and penicillin/streptomycin were purchased from HyClone Laboratories; GE Healthcare Life Sciences. Ursolic acid, 3-(4,5-dimethylthiazol-2-yl)-2,5diphenyltetrazolium bromide (MTT), and other chemicals were of analytical grade from Sigma-Aldrich; EMD Millipore (Billerica, MA, USA) unless otherwise specified. The pan-caspase inhibitor z-VAD-fmk was purchased from EMD Millipore. Caspase-3 and Caspase-9 Colorimetric Assay kits were from R\&D Systems, Inc. (Minneapolis, MN, USA). The anti-caspase-3 (cat. no. GTX110543), anti-caspase-9 (cat. no. GTX112888), anti-phosphorylated (p)-AKT ${ }^{\mathrm{Ser} 473}$ (cat. no. GTX28932), anti-AKT (cat. no. GTX121937), anti-p-BAD ${ }^{\text {Ser136 }}$ (cat. no. GTX50136), anti-BAD (cat.no.GTX130108), anti-Bax (cat.no.GTX109683), anti-Bcl-2 (cat. no. GTX100064), anti-Bcl-xL (cat. no. GTX84834), and anti- $\beta$-actin (cat. no. GTX109639) antibodies, and the anti-rabbit (cat. no. GTX213110-01) and anti-mouse (cat. no. GTX213111-01) IgG horseradish peroxidase (HRP)-linked antibodies were all purchased from GeneTex, Inc. (Hsinchu, Taiwan). The reactive oxygen species (ROS) indicator $\mathrm{H}_{2}$ DCFDA and the mitochondrial membrane potential $(\Delta \Psi \mathrm{m})$ detector $\mathrm{DiOC}_{6}(3)$ were obtained from Molecular Probes; Thermo Fisher Scientific, Inc. (Waltham, MA, USA).

Cell viability assay. Cell viability was evaluated with an MTT method, as previously described $(23,28)$. Briefly, the CAR or HGF cells were seeded in a 96-well plate at a density of $1 \times 10^{4}$ cells/well and treated with different concentrations $(50,100,150$ or $200 \mu \mathrm{M})$ of ursolic acid prior to pre-incubation with or without $10 \mu \mathrm{M} \mathrm{z}$-VAD-fmk (pan-caspase inhibitor) for $1.5 \mathrm{~h}$ at $37^{\circ} \mathrm{C}$. After $24 \mathrm{~h}$, the medium was removed, and the cells were cultured with $0.5 \mathrm{mg} / \mathrm{ml}$ MTT solution for an additional $2 \mathrm{~h}$ at $37^{\circ} \mathrm{C}$. Subsequently, $100 \mu \mathrm{l}$ DMSO was used to dissolve the blue formazan product, and cell viability was spectrophotometrically measured at the absorbance of $570 \mathrm{~nm}$, as previously described $(29,30)$.

Kinetic cell confluence assay. The cell confluence experiment was monitored using the IncuCyte ZOOM system (Essen BioScience, Ann Arbor, MI, USA), as previously described $(1,31)$. In brief, the CAR cells at a density of $1 \times 10^{4}$ cells per well were seeded in a 96 -well plate and then exposed to $0,50,100$ and $200 \mu \mathrm{M}$ of ursolic acid for $48 \mathrm{~h}$. Data collection was performed every $2 \mathrm{~h}$ until $48 \mathrm{~h}$, and images of the morphological changes were captured and collected every $12 \mathrm{~h}$ using the IncuCyte ZOOM system (Essen BioScience).

In vitro caspase activity assay. The activities of caspase-3 and caspase- 9 were detected using Caspase- 3 and Caspase- 9 

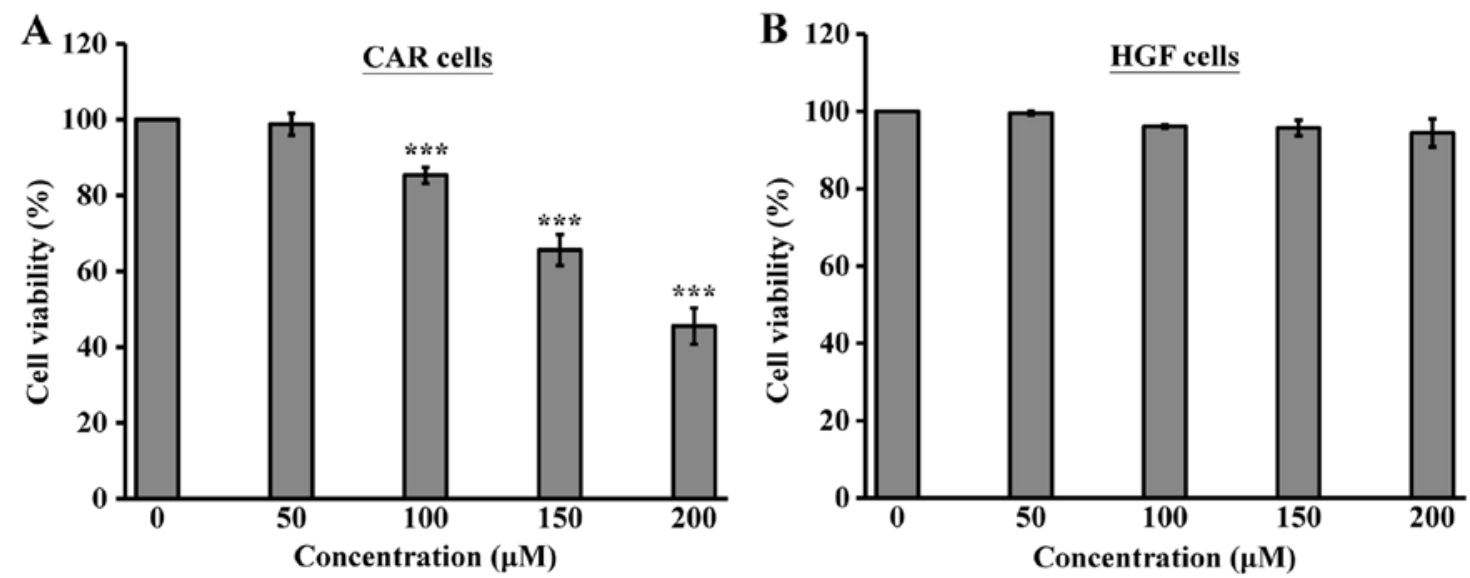

Figure 1. Effects of ursolic acid on cell viability of CAR and normal HGF cells. The two cell types were placed in 96 -well plates at a density of $1 \times 10^{4}$ cells/well and were treated with $0,50,100,150$ and $200 \mu \mathrm{M}$ of ursolic acid for $24 \mathrm{~h}$. The cell viability of (A) CAR and (B) HGF cells was determined using the 3-(4,5-dimethylthiazol-2-yl)-2,5-diphenyltetrazolium bromide assay. Each data point represents the mean \pm standard deviation of experiments independently repeated three times. ${ }^{* * * *} \mathrm{P}<0.001$, vs. the untreated control group.

Colorimetric Assay kits (R\&D Systems Inc.) with synthetic tetrapeptides [Asp-Glu-Val-Asp (DEAD) for caspase-3; Leu-Glu-His-Asp (LEHD) for caspase-9] labeled with $p$-nitroaniline (pNA) to link to the caspase-specific substrate. The CAR cells $\left(5 \times 10^{6}\right.$ cells per $75 \mathrm{~T}$ flask) were treated with or without 50, 100, 150 and $200 \mu \mathrm{M}$ of ursolic acid for $24 \mathrm{~h}$. The cell lysates were then harvested, and the supernatants were incubated with the supplied reaction buffer with dithiothreitol and DEAD-pNA or LEHD-pNA as substrates at $37^{\circ} \mathrm{C}$ for $2 \mathrm{~h}$ in the dark according to the manufacturer's protocols.

Immunoblotting analysis. The CAR cells $\left(5 \times 10^{6}\right.$ cells per $75 \mathrm{~T}$ flask) were treated with or without 100, 150 and $200 \mu \mathrm{M}$ of ursolic acid for $12 \mathrm{~h}$. The cells were then harvested and lysed with Trident RIPA lysis buffer (GeneTex, Inc.). The Pierce BCA protein assay kit was used to detect the protein concentration, following which an equal quantity of the protein sample (40 $\mu \mathrm{g})$ was subjected to electrophoresis on a $10-12 \%$ sodium dodecyl sulfate-polyacrylamide gel, as previously described $(32,33)$. The separated protein was transferred onto the Immobilon-P Transfer membrane (Merck Millipore, Darmstadt, Germany) via use of electroblotting. Thereafter, the membranes were soaked in 5\% skim milk and individually incubated overnight with primary antibodies, including caspase-3, caspase-9, p-AKT ${ }^{\text {Ser473 }}, \mathrm{AKT}^{\mathrm{p}} \mathrm{p}-\mathrm{BAD}^{\mathrm{Ser} 136}$, BAD, Bax, Bcl-2, Bcl-xL (all 1:1,000 dilution) and $\beta$-actin (1:5,000 dilution) at $4^{\circ} \mathrm{C}$, followed by incubation with the appropriate HRP-conjugated secondary antibodies (1:10,000 dilution) for $1 \mathrm{~h}$ at room temperature to hybridize targeted protein using Immobilon Western Chemiluminescent HRP substrate (Merck Millipore), as previously described $(34,35)$. All bands of immunoblots were normalized to $\beta$-actin, and their densitometric quantification was performed using NIH ImageJ 1.47 software (National Institutes of Health, Bethesda, MD, USA).

Measurements of $\Delta \Psi_{m}$ and ROS production using flow cytometry. The CAR cells $\left(2 \times 10^{5}\right.$ cells $\left./ \mathrm{ml}\right)$ in 12 -well plates were exposed to $0,50,100,150$ and $200 \mu \mathrm{M}$ of ursolic acid for $12 \mathrm{~h}$. The cells were then collected and incubated with $500 \mu \mathrm{l}$ of $\mathrm{H}_{2}$ DCF-DA (ROS detector dye, $10 \mu \mathrm{M}$ ) and $50 \mathrm{nM}$ of the cell-permeant $\Delta \Psi \mathrm{m}$ probe, $\mathrm{DiOC}_{6}(3)$, at $37^{\circ} \mathrm{C}$ for $30 \mathrm{~min}$ using flow cytometry, as previously described $(33,36)$.

Statistical analysis. The values are expressed as the mean \pm standard deviation from at least three separate experiments. Data analysis was performed using SPSS software version 16.0 (SPSS, Inc., Chicago, IL, USA). The differences were analyzed using one-way analysis of variance followed by Dunnett's test. $\mathrm{P}<0.001$ was considered indicate a statistically significant difference.

\section{Results}

Effects of ursolic acid on the viability of cisplatin-resistant human oral cancer CAR cells. The cytotoxicity of ursolic acid towards CAR cells was first investigated. The cells were cultured with various concentrations of ursolic acid $(50,100$, 150 and $200 \mu \mathrm{M}$ ) for $24 \mathrm{~h}$. Cell viability was evaluated using the MTT assay. The results demonstrated that ursolic acid at 100,150 and $200 \mu \mathrm{M}$ significantly reduced the viability of CAR cells in a concentration-dependent manner (Fig. 1A). By contrast, ursolic acid exerted no toxicity towards the normal HGF cells (Fig. 1B). Similarly, the cell confluence of the cultured CAR cells following exposure to the different concentrations $(0,50,100$ and $200 \mu \mathrm{M})$ of ursolic acid was monitored using the IncuCyte ZOOM system instrument at the 2-h period. The data showed that the inhibition of CAR cell confluence appeared following incubation with $200 \mu \mathrm{M}$ ursolic acid, compared with the control, when incubated for up to $48 \mathrm{~h}$ (Fig. 2). In addition, images of the cultured CAR cells captured at 12-h intervals demonstrated that ursolic acid at $200 \mu \mathrm{M}$ induced cell morphology changes and a decrease of cell confluence, and triggered CAR cell death (Fig. 3). Therefore, these finding suggested that ursolic acid at $200 \mu \mathrm{M}$ produced a marked reduction in the viability of CAR cells.

Effects of the pan-caspase inhibitor z-VAD-fmk against ursolic acid-induced caspase-dependent apoptosis of CAR cells. To further examine whether the observed suppression 


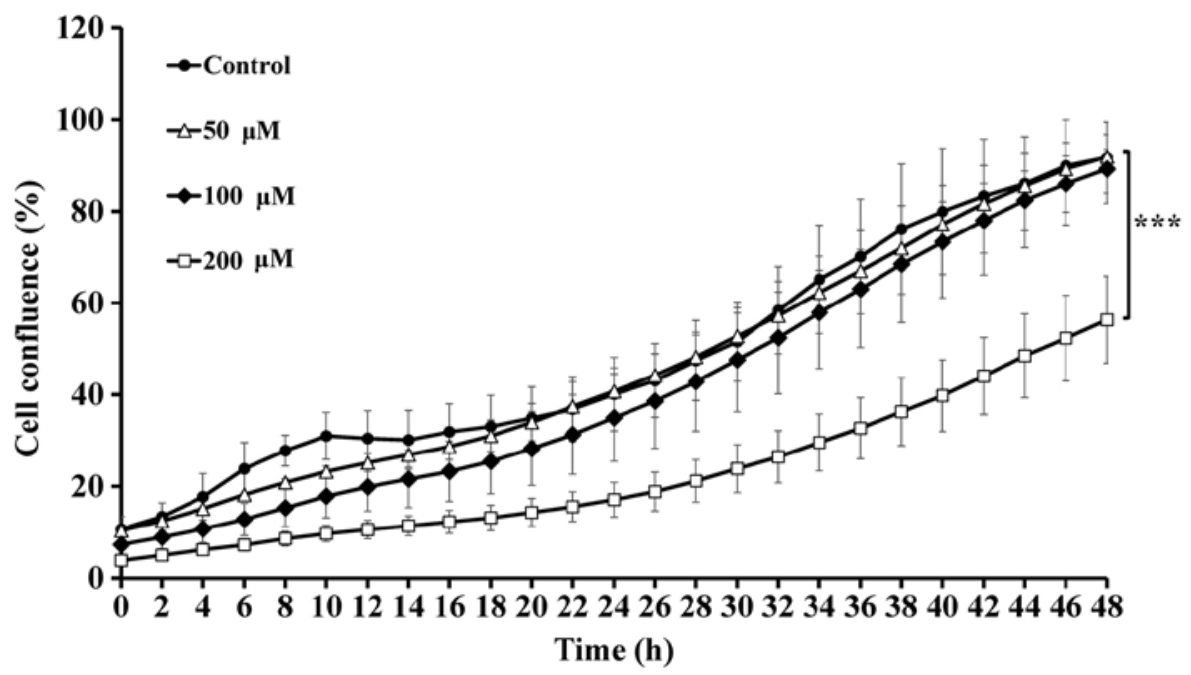

Figure 2. Effects of ursolic acid on the cell confluence of CAR cells. Cells were incubated with 0,50,100 and $200 \mu \mathrm{M}$ of ursolic acid for various durations. The cell confluence was determined using the IncuCyte ZOOM system. Data are presented as the mean \pm standard deviation $(\mathrm{n}=3)$. ${ }^{* * * *} \mathrm{P}<0.001$, vs. untreated control.

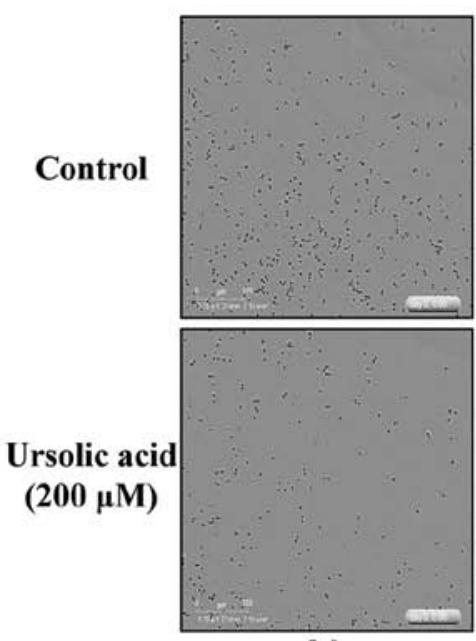

$\mathbf{0 ~ h}$
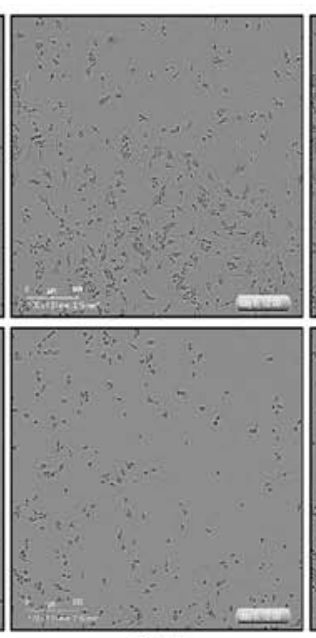

$12 \mathrm{~h}$

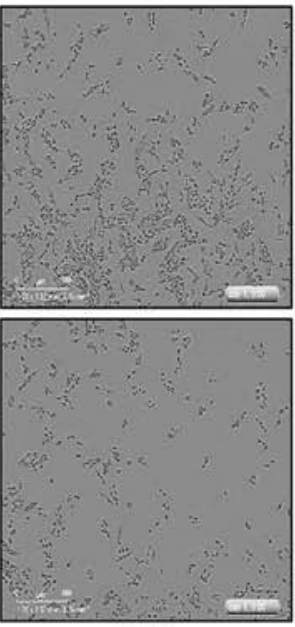

$24 \mathrm{~h}$

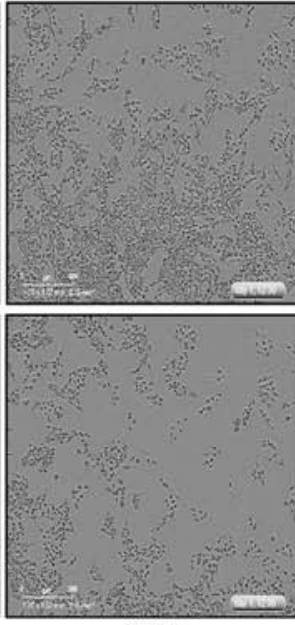

$36 \mathrm{~h}$

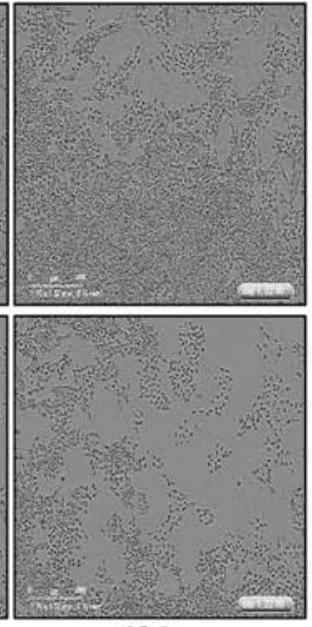

$48 \mathrm{~h}$

Figure 3. Effects of ursolic acid on the morphology and confluence of CAR cells. Cells were incubated with $200 \mu \mathrm{M}$ of ursolic acid for $0,12,24,36$ and $48 \mathrm{~h}$. Images of morphology and density was captured and analyzed using the IncuCyte ZOOM system. Scale bar, $300 \mu \mathrm{m}$.

of cell viability involved apoptotic machinery, the cells were pretreated with $10 \mu \mathrm{M}$ z-VAD-fmk and then exposed to $200 \mu \mathrm{M}$ ursolic acid for $24 \mathrm{~h}$. The results showed that, without prior incubation of the CAR cells with $10 \mu \mathrm{M} z-V A D-f m k$, the inhibition of cell viability was significantly inhibited by ursolic acid at $200 \mu \mathrm{M}$ (Fig. 4). Therefore, ursolic acid inhibited CAR cell viability via the caspase pathway.

Effects of ursolic acid on caspase-3/-9-dependent apoptosis of CAR cells. To investigate whether the ursolic acid-induced apoptosis in CAR cells is associated with the intrinsic pathway (caspase- 3 and caspase-9) following treatment with various concentrations $(0,50,100,150$ and $200 \mu \mathrm{M})$ of ursolic acid, the activities and protein levels of caspase-3 and -9 were individually assayed using a colorimetric assay and western blot analysis. The results indicated that ursolic acid significantly promoted the activities of caspase- 3 at 100, 150 and $200 \mu \mathrm{M}$ concentrations in a concentration-dependent manner (Fig. 5A). Similarly, the activity of caspase-9 was markedly enhanced

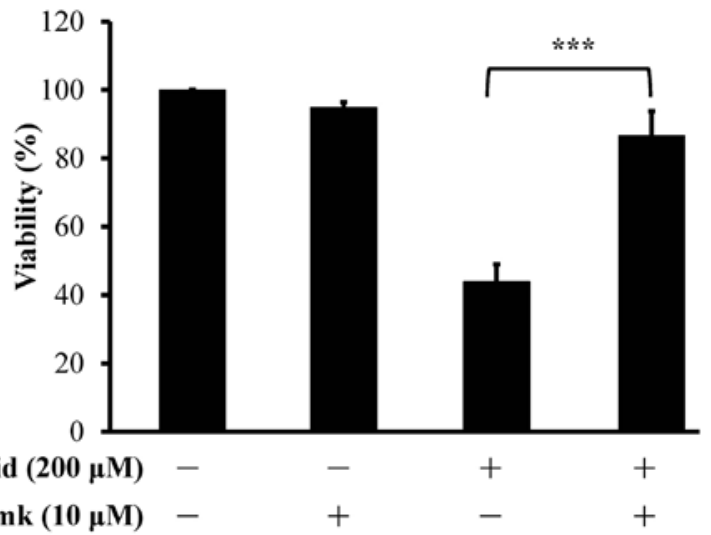

Figure 4. Effects of the pan-caspase inhibitor z-VAD-fmk on the apoptotic death of ursolic acid-treated CAR cells. Cells were pretreated in the presence or absence of $10 \mu \mathrm{M} \mathrm{z}$-VAD-fmk and then exposed to $200 \mu \mathrm{M}$ ursolic acid for $24 \mathrm{~h}$. Cell viability was assessed using a 3-(4,5-dimethylthiazol2-yl)-2,5-diphenyltetrazolium bromide assay. Data are presented as the mean \pm standard deviation $(n=3)$. ${ }^{* * *} \mathrm{P}<0.05$, vs. the ursolic acid-treated cells. 

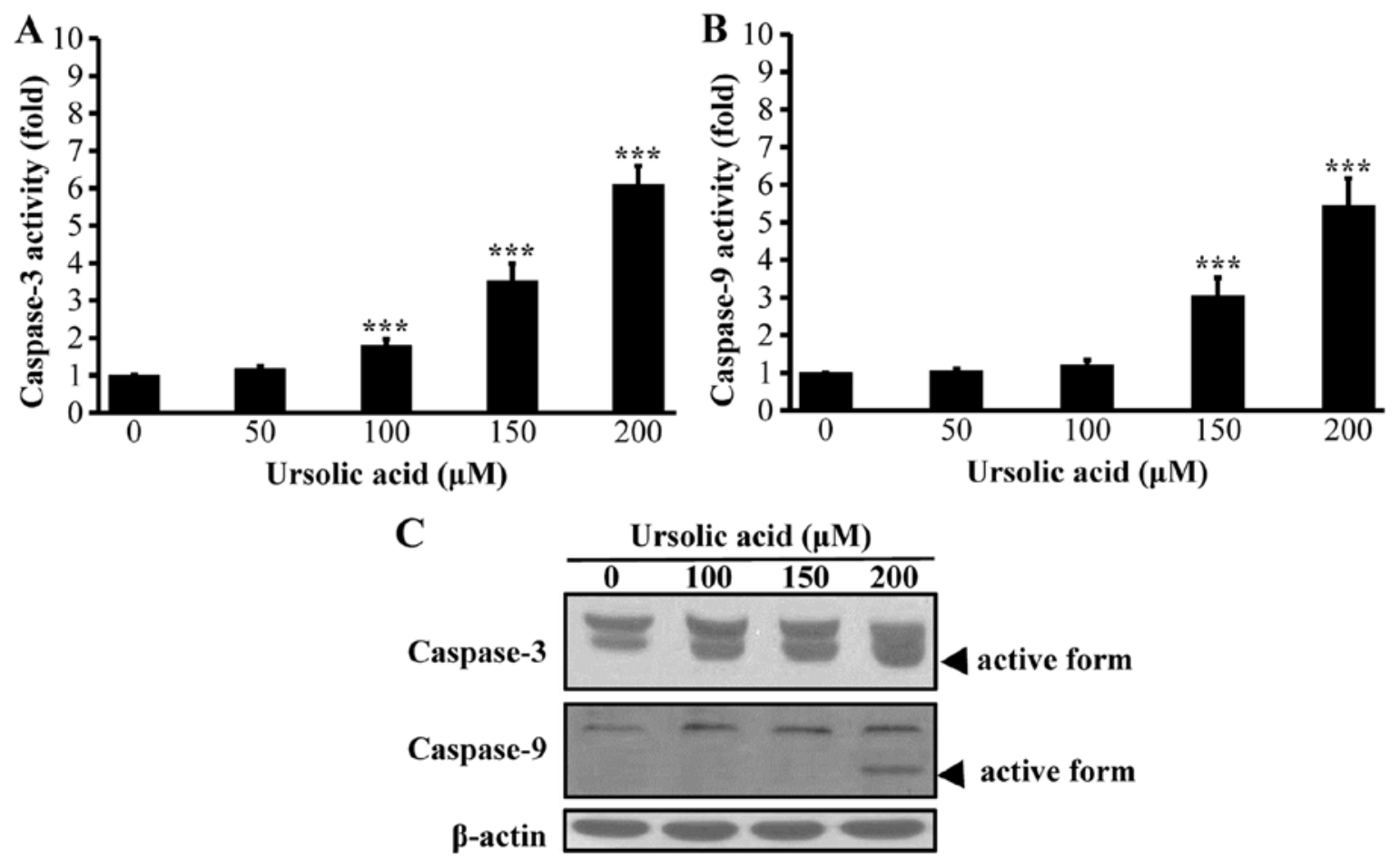

Figure 5. Effects of ursolic acid on activities of caspase-9 and caspase-3 in CAR cells. (A) Caspase-3 and (B) caspase-9 activities were analyzed in CAR cells treated with $0,50,100,150$ and $200 \mu \mathrm{M}$ of ursolic acid for $24 \mathrm{~h}$. Data are presented as the mean \pm standard deviation ( $=3$ ). ${ }^{* * *} \mathrm{P}<0.001$, vs. untreated control. (C) Anti-caspase-3 and anti-caspase-9 antibodies were used to examine caspase activation (arrows indicate activated caspase-3 and caspase-9) by immunoblotting analysis.

in the CAR cells exposed to ursolic acid $(150$ and $200 \mu \mathrm{M}$; Fig. 5B). Ursolic acid markedly increased the protein level of the active form of caspase-3 (Fig. 5C). In addition, it promoted an increase in the protein level of cleaved caspase-9 (Fig. 5C). On the basis of these results, it was suggested that the apoptotic mechanism of ursolic acid in CAR cells was mediated via caspase-3/-9-dependent signaling.

Effects of ursolic acid on the levels of ROS production and the $\triangle \Psi m$ of CAR cells. As ursolic acid affected the activation of caspase-9, it was hypothesized that ursolic acid-induced apoptosis may be regulated via the mitochondria-dependent pathway. The CAR cells were treated with ursolic acid at various concentrations for $12 \mathrm{~h}$. The levels of ROS production and $\Delta \Psi \mathrm{m}$ were measured by flow cytometric assays. The results indicated that ursolic acid promoted the production of ROS (Fig. 6A), but decreased the level of $\Delta \Psi \mathrm{m}$ (Fig. 6B) in the CAR cells, and these effects were concentrationdependent. Based on these findings, mitochondrial dysfunction may be required for the ursolic acid-induced apoptosis of CAR cells.

Effects on apoptosis-related protein levels of CAR cells treated with ursolic acid. To further understand the mechanism of apoptosis in CAR cells, the protein signals of AKT, $\mathrm{BAD}, \mathrm{Bax}, \mathrm{Bcl}-2$ and Bcl-xL were determined in the ursolic acid-treated cells. Ursolic acid at 100, 150 and $200 \mu \mathrm{M}$ for 12 $\mathrm{h}$ decreased the phosphorylation of AKT on Ser473 (p-AKT) and BAD on Ser136 (p-BAD), decreased the protein levels of Bcl-2 and Bcl-xL, and increased the expression of BAD and Bax (Fig. 7A and B). These findings showed that ursolic

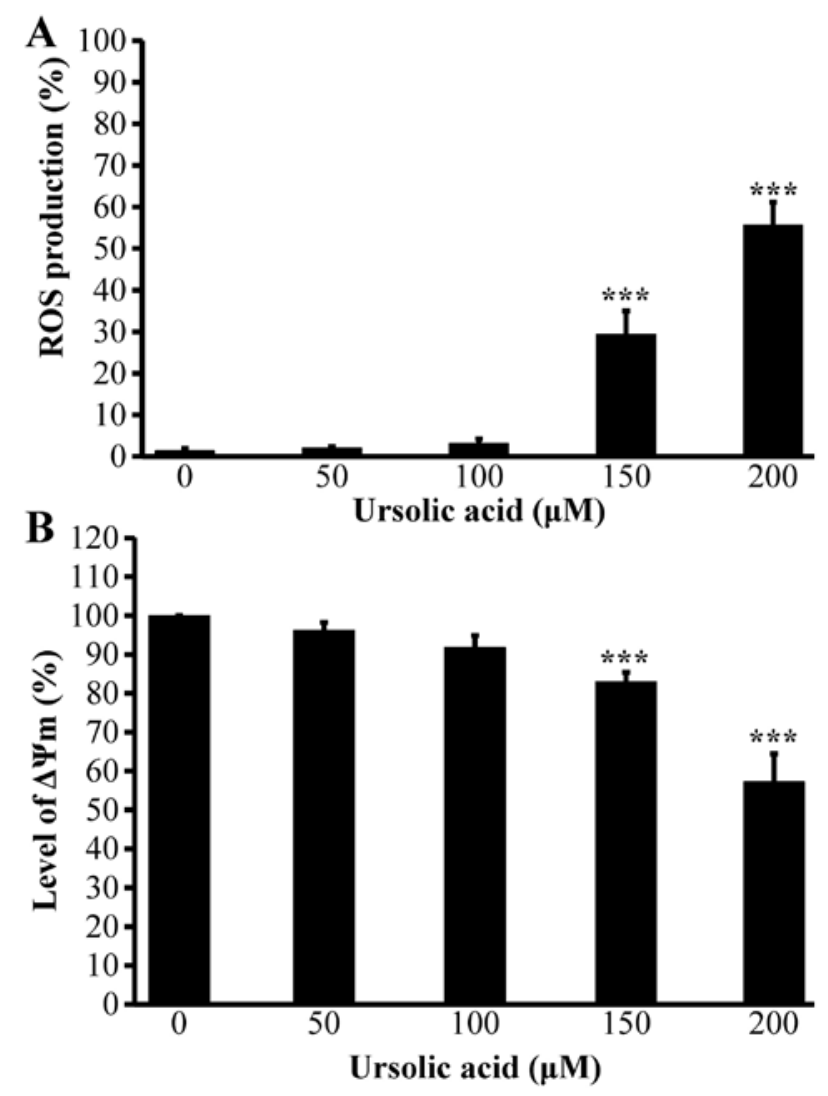

Figure 6. Effects of ursolic acid on ROS production and $\triangle \Psi \mathrm{m}$ in CAR cells Cells were incubated with $0,50,100,150$ and $200 \mu \mathrm{M}$ of ursolic acid for $12 \mathrm{~h}$. (A) ROS levels were assessed by staining with $\mathrm{H}_{2}$ DCFDA; (B) loss of $\Delta \Psi \mathrm{m}$ was measured with $\operatorname{DiOC}(3)_{6}$ and flow cytometry. Data are presented as the mean \pm standard deviation $(n=3)$. ${ }^{* * *} \mathrm{P}<0.001$, vs. untreated control. ROS, reactive oxygen species; $\Delta \Psi \mathrm{m}$, mitochondrial membrane potential. 
A

\begin{tabular}{|c|c|c|c|c|}
\hline \multirow[b]{2}{*}{ p-AKT ${ }^{\text {Ser473 }}$} & 0 & 100 & 150 & 200 \\
\hline & 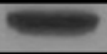 & $=$ & - & $=$ \\
\hline \multirow{3}{*}{ AKT } & 1.0 & 1.1 & 0.4 & 0.5 \\
\hline & $=$ & $=$ & $=$ & $=$ \\
\hline & 1.0 & 1.0 & 1.0 & 1.0 \\
\hline \multirow{2}{*}{ p-BAD ${ }^{\operatorname{Ser} 136}$} & $t$ & $=$ & 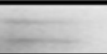 & 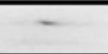 \\
\hline & 1.0 & 1.0 & 0.3 & 0.1 \\
\hline \multirow[t]{2}{*}{ BAD } & & $\overline{-}$ & $=$ & $=$ \\
\hline & 1.0 & 3.2 & 4.5 & 6.7 \\
\hline
\end{tabular}

B

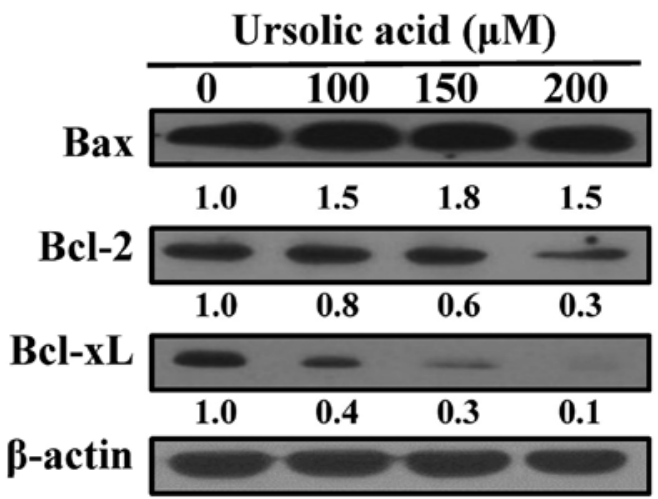

Figure 7. Effects of ursolic acid on apoptotic signaling of CAR cells. Cells were treated without or with 100,150 and $200 \mu \mathrm{M}$ ursolic acid for $12 \mathrm{~h}$, and cell lysates were collected and blotted using specific antibodies, including (A) p-AKT ${ }^{\text {Ser473 }}, \mathrm{AKT}, \mathrm{p}-\mathrm{BAD}^{\mathrm{Ser} 136}$ and BAD, and (B) Bax, Bcl-2 and $\mathrm{Bcl}-\mathrm{xL}$, by immunoblot analysis. Each lane of protein signaling is normalized to $\beta$-actin. p-, phosphorylated; Bcl-2, B-cell lymphoma 2; BAD, $\mathrm{Bcl}-2$-associated agonist of cell death; Bax, Bcl-2-associated $\mathrm{X}$ protein; Bcl-xL, Bcl-extra large.

acid induced apoptotic CAR cell death through a mitochondria-dependent pathway.

\section{Discussion}

Cisplatin, including oxaliplatin and carboplatin, is a member of platinum-containing chemotherapeutic agents $(37,38)$. Unfortunately, cisplatin resistance remains the major cause of treatment failure in OSCC (39). Therefore, the identification of novel drugs that can enhance the inhibition of cell proliferation or target cisplatin-resistant cancer cells is of paramount importance. In our previous studies $(8,40)$, human cisplatin-resistant oral cancer CAR cells were established and the differences between the parental cell line (CAL 27) and CAR cells were investigated. The preliminary aim was to examine the effects on cell morphology, viability (40) and the expression of ATP-binding cassette B1, a multidrug resistance protein 1 (MDR1) in CAL 27 and CAR cells prior to cisplatin treatment. It was found that CAR cells were resistant to $80 \mu \mathrm{M}$ cisplatin compared with the parental CAL 27 cells. The protein expression of MDR1 was higher in CAR cells than in CAL 27 cells. To date, CAR cells have been applied as a cell platform to assess various photochemicals, novel compounds and cell conditioned media $(1,6-8,40,41)$.
Ursolic acid is a potent phytochemical and its use is popular in natural medicinal plants (16-21). It has been reported that ursolic acid has anticancer effects on chemoresistant cells. For example, ursolic acid attenuates temozolomide resistance in glioblastoma cells by downregulating the expression of $O^{6}$-methylguanine-DNA methyltransferase in vitro and in vivo (42). Ursolic acid also inhibits the growth of gemcitabine-resistant MIA PaCa-2 human pancreatic cancer cells and induces apoptosis through c-Jun N-terminal kinase and phosphoinositide 3-kinase/AKT/nuclear factor- $\kappa \mathrm{B}$ pathways (43). Ursolic acid enhances the cytotoxicity in adriamycin-resistant HL60/ADR, K562/ADR, and MCF-7/ADR cells (44), and induces doxorubicin-resistant HepG2 cell death via the apoptosis-inducing factor-dependent pathway (45). In the present study, it was shown that $200 \mu \mathrm{M}$ ursolic acid significantly inhibited the cell viability (Fig. 1A) and cell confluence (Fig. 2; https://goo.gl/zytqBi) of CAR cells. Ursolic acid was relatively non-toxic to normal HGF cells (Fig.1B), and this result is in agreement with previous studies on non-tumorigenic cells, including human normal CCD841 and LO2 cell lines (46) and normal bone marrow mononuclear cells (47). Ursolic acid led to the selective cell death of human cisplatin-resistant CAR cells, rather than normal cells. These results provide novel information on the oral anticancer activity of ursolic acid in cisplatin-resistant CAR cells.

It has been demonstrated that ursolic acid inhibits cell proliferation and apoptosis in human oral cancer $\mathrm{KB}$ cells (48). Ursolic acid also suppresses the transcription of cyclooxygenase-2 in human oral epithelial cells (49). However, the molecular mechanism involved in the effect of ursolic acid on apoptosis in drug-resistant OSCC remains to be fully elucidated. In the present study, ursolic acid was investigated for its antitumor effects and signaling transduction in apoptosis of CAR cells. Ursolic acid significantly inhibited the proliferation of the CAR cells (Figs. 1 and 3). Ursolic acid-induced apoptosis was confirmed by the pan-caspase inhibitor, z-VAD-fmk, which reversed the reduction in cellular viability in the ursolic acid-treated CAR cells (Fig. 4). Ursolic acid increased the activities of caspase-3/caspase-9 and the protein levels of cleavage-activated caspase- 3 and caspase-9 in the CAR cells (Fig. 5). Ursolic acid also increased ROS production and decreased $\Delta \Psi \mathrm{m}$ in CAR cells (Fig. 6). These results suggested that ursolic acid induced apoptosis through a mitochondria-dependent pathway in CAR cells.

BAD is a member of the Bcl-2 family. BAD has a pro-apoptotic role in the process of apoptosis $(50,51)$. Dephosphorylated BAD promotes apoptosis and inactivates other anti-apoptotic Bcl-2 family proteins, including Bcl-2, Bcl-xL and Bcl-w (50). The BAD protein is phosphorylated on Serine 99 and Serine 134 sites (Serine 136 site in mice) by AKT; the BAD protein dissociates from the heterodimer of $\mathrm{Bcl}-2 / \mathrm{Bcl}-\mathrm{xL}$ and then binds to the 14-3-3 protein in the cytoplasm with an inactive form. Therefore, the free Bcl-2 and Bcl-xL can inhibit apoptosis (52). AKT signal transduction is involved in anti-apoptotic effects and cell proliferation. Piticlisib (GDC-0941), a PI3K inhibitor, has been demonstrated to inhibit the phosphorylation of BAD on Serine 75 and Serine 99 sites and to induce glioblastoma cell apoptosis in clinical trials (53). Burpalisib (BKM120) 


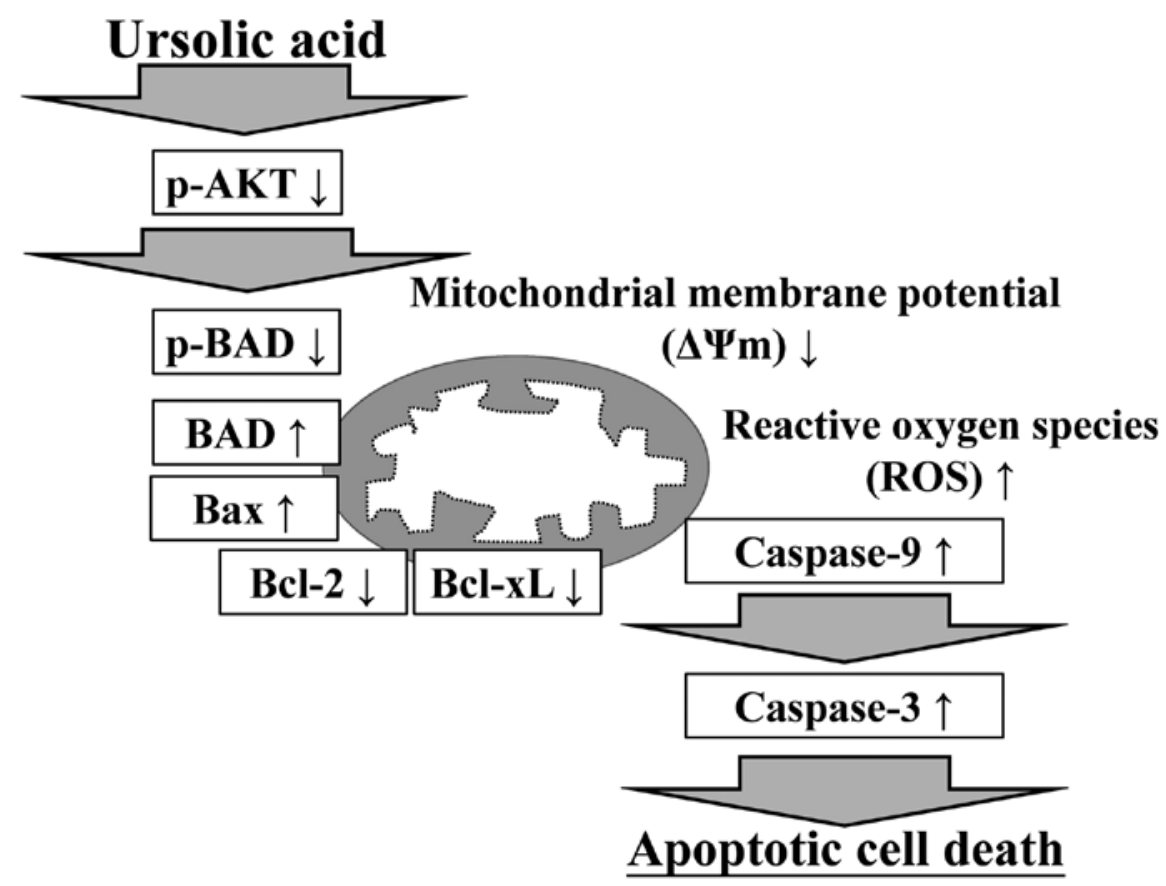

Figure 8. An integrated model of the apoptosis-related signaling pathway induced by ursolic acid in human cisplatin-resistant oral cancer CAR cells. p-, phosphorylated; Bcl-2, B-cell lymphoma 2; BAD, Bcl-2-associated agonist of cell death; Bax, Bcl-2-associated X protein; Bcl-xL, Bcl-extra large; ROS, reactive oxygen species; $\Delta \Psi \mathrm{m}$, mitochondrial membrane potential.

has also been shown to inhibit the phosphorylation of BAD on Serine 99 site via the PI3K/AKT pathway in T and B cell acute lymphoblastic leukemia (54). It has been reported that ursolic acid suppresses the phosphorylation and activation of $\mathrm{AKT}$, and then induces apoptosis in leukemia cells $(55,56)$, colon cancer cells $(46,57)$, gemcitabine-resistant human pancreatic cancer cells (43), human bladder cancer cells (58), prostate cancer cells $(59,60)$, and hepatocellular carcinoma cells $(61,62)$. The results of the present study showed that ursolic acid suppressed the phosphorylation of AKT and then inhibited the level of phosphorylated BAD downstream. In addition, ursolic acid decreased the protein levels of Bcl-2 and Bcl-xL in CAR cells (Fig. 7). These findings suggested that ursolic acid suppressed CAR cell growth and induced mitochondria-dependent apoptosis through suppressing the phosphorylation of the AKT/BAD pathway.

In conclusion, the results of the present study supported the hypothesis that ursolic acid-induced apoptosis may involve the AKT/BAD pathway. The suggested integrated model of the molecular signaling induced by ursolic acid in CAR cells is summarized in Fig. 8. The present study is the first, to the best of our knowledge, to demonstrate that ursolic acid represents a promising candidate as an oral anticancer drug, and it may be used as an agent for treating drug-resistant oral cancer in the future.

\section{Acknowledgements}

The authors would like to thank Mr. Meng-Jou Liao (Tekon Scientific Corporation, Taipei, Taiwan), Mr. Chin-Chen Lin (Tekon Scientific Corporation) and Mr. Chang-Wei Li (AllBio Science Inc., Taichung, Taiwan) for their support with techniques and equipment.

\section{Funding}

The present study was supported by the China Medical University Hospital (grant no. DMR-107-123).

\section{Availability of data and materials}

The datasets used during the present study are available from the corresponding author upon reasonable request.

\section{Authors' contributions}

CFC, HJH and TDW conceived and designed the experiments; CFC, JSY, WKC, CCL and JHC performed the experiments. CFC, HYC, SCT and YNJ analyzed the data; CFC, HJH and TDW wrote and modified the manuscript. All authors read and approved the manuscript and agree to be accountable for all aspects of the research in ensuring that the accuracy or integrity of any part of the work are appropriately investigated and resolved.

\section{Ethics approval and consent to participate}

Not applicable.

\section{Patient consent for publication}

Not applicable.

\section{Competing interests}

The authors declare that they have no competing interests. 


\section{References}

1. Lee MR, Lin C, Lu CC, Kuo SC, Tsao JW, Juan YN, Chiu HY, Lee FY, Yang JS and Tsai FJ: YC-1 induces $G_{0} / G_{1}$ phase arrest and mitochondria-dependent apoptosis in cisplatin-resistant human oral cancer CAR cells. Biomedicine 7: 12, 2017.

2. Wang ZX, Bian HB, Yang JS, De W and Ji XH: Adenovirus-mediated suicide gene therapy under the control of Cox-2 promoter for colorectal cancer. Cancer Biol Ther 8 : 1480-1488, 2009.

3. Ferguson BL, Barber S, Asher IH and Wood CR: Role of oral microbial infections in oral cancer. Dent Clin North Am 61: 425-434, 2017.

4. Chen S, Hu H, Miao S, Zheng J, Xie Z and Zhao H: Anti-tumor effect of cisplatin in human oral squamous cell carcinoma was enhanced by andrographolide via upregulation of phospho-p53 in vitro and in vivo. Tumour Biol 39: 1010428317705330, 2017.

5. Kumari K, Haragannavar VC, Kumar KV, Prasad K and Nambiar S: Basaloid Squamous Cell Carcinoma of Tongue: A report with emphasis on immunohistochemistry. J Clin Diagn Res 11: ZD16-ZD18, 2017.

6. Chang CH, Lee CY, Lu CC, Tsai FJ, Hsu YM, Tsao JW, Juan YN, Chiu HY, Yang JS and Wang CC: Resveratrol-induced autophagy and apoptosis in cisplatin-resistant human oral cancer CAR cells: A key role of AMPK and Akt/mTOR signaling. Int J Oncol 50 873-882, 2017.

7. Yuan CH, Horng CT, Lee CF, Chiang NN, Tsai FJ, Lu CC, Chiang JH, Hsu YM, Yang JS and Chen FA: Epigallocatechin gallate sensitizes cisplatin-resistant oral cancer CAR cell apoptosis and autophagy through stimulating AKT/STAT3 pathway and suppressing multidrug resistance 1 signaling. Environ Toxicol 32: 845-855, 2017.

8. Chang PY, Peng SF, Lee CY, Lu CC, Tsai SC, Shieh TM, Wu TS, Tu MG, Chen MY and Yang JS: Curcumin-loaded nanoparticles induce apoptotic cell death through regulation of the function of MDR1 and reactive oxygen species in cisplatin-resistant CAR human oral cancer cells. Int J Oncol 43: 1141-1150, 2013.

9. Wang Z, Zhang B, Jiang L, Zeng X, Chen Y, Feng X, Guo Y and Chen Q: RACK1, an excellent predictor for poor clinical outcome in oral squamous carcinoma, similar to Ki67. Eur J Cancer 45: 490-496, 2009.

10. Schoop RA, Noteborn MH and Baatenburg de Jong RJ: A mouse model for oral squamous cell carcinoma. J Mol Histol 40 177-181, 2009.

11. Chen SC, Chang PM and Yang MH: Cisplatin/tegafur/ uracil/irinotecan triple combination therapy for recurrent/ metastatic head and neck squamous cell carcinoma: A phase I/II clinical study. Oncologist 21: 537-538, 2016.

12. Štulhofer Buzina D, Martinac I, Ledić Drvar D, Čeović R, Bilić I and Marinović B: Adverse reaction to cetuximab, an epidermal growth factor receptor inhibitor. Acta Dermatovenerol Croat 24: 70-72, 2016.

13. El-Deftar MF, El Gerzawi SM, Abdel-Azim AA and Tohamy SM: Prognostic significance of ploidy and S-phase fraction in primary intraoral squamous cell carcinoma and their corresponding metastatic lymph nodes. J Egypt Natl Canc Inst 24: 7-14, 2012.

14. El-Naaj IA, Leiser Y, Shveis M, Sabo E and Peled M: Incidence of oral cancer occult metastasis and survival of T1-T2N0 oral cancer patients. J Oral Maxillofac Surg 69: 2674-2679, 2011.

15. Lee SY, Kim YJ, Chung SO and Park SU: Recent studies on ursolic acid and its biological and pharmacological activity. EXCLI J 15: 221-228, 2016

16. Kashyap D, Tuli HS and Sharma AK: Ursolic acid (UA): A metabolite with promising therapeutic potential. Life Sci 146 201-213, 2016.

17. Katashima CK, Silva VR, Gomes TL,Pichard C and Pimentel GD: Ursolic acid and mechanisms of actions on adipose and muscle tissue: A systematic review. Obes Rev 18: 700-711, 2017.

18. Woźniak Ł, Skapska S and Marszałek K: Ursolic acid-a pentacyclic triterpenoid with a wide spectrum of pharmacological activities. Molecules 20: 20614-20641, 2015.

19. Huang J, Zhang Y, Dong L, Gao Q, Yin L, Quan H, Chen R, Fu X and Lin D: Ethnopharmacology, phytochemistry, and pharmacology of Cornus officinalis Sieb. et Zucc. J Ethnopharmacol 213: 280-301, 2018

20. Zhang L, Wei K, Xu J, Yang D, Zhang C, Wang Z and Li M: Belamcanda chinensis (L.) DC-An ethnopharmacological, phytochemical and pharmacological review. J Ethnopharmacol 186: $1-13,2016$.
21. Xie C, Xie Z, Xu X and Yang D: Persimmon (Diospyros kaki L.) leaves: A review on traditional uses, phytochemistry and pharmacological properties. J Ethnopharmacol 163: 229-240, 2015.

22. Novotný L, Vachálková A and Biggs D: Ursolic acid: An anti-tumorigenic and chemopreventive activity. Minireview. Neoplasma 48: 241-246, 2001.

23. Lu CC, Huang BR, Liao PJ and Yen GC: Ursolic acid triggers nonprogrammed death (necrosis) in human glioblastoma multiforme DBTRG-05MG cells through MPT pore opening and ATP decline. Mol Nutr Food Res 58: 2146-2156, 2014

24. Shanmugam MK, Dai X, Kumar AP, Tan BK, Sethi G and Bishayee A: Ursolic acid in cancer prevention and treatment: Molecular targets, pharmacokinetics and clinical studies. Biochem Pharmacol 85: 1579-1587, 2013.

25. Kuttan G, Pratheeshkumar P, Manu KA and Kuttan R: Inhibition of tumor progression by naturally occurring terpenoids. Pharm Biol 49: 995-1007, 2011.

26. Lernoux M, Schnekenburger M, Dicato M and Diederich M: Anti-cancer effects of naturally derived compounds targeting histone deacetylase 6-related pathways. Pharmacol Res 129: 337-356, 2018.

27. Gosepath EM, Eckstein N, Hamacher A, Servan K, von Jonquieres $\mathrm{G}$, Lage H, Györffy B, Royer HD and Kassack MU: Acquired cisplatin resistance in the head-neck cancer cell line Cal27 is associated with decreased DKK1 expression and can partially be reversed by overexpression of DKK1. Int J Cancer 123: 2013-2019, 2008.

28. Chang LC, Hsieh MT, Yang JS, Lu CC, Tsai FJ, Tsao JW, Chiu YJ, Kuo SC and Lee KH: Effect of bis(hydroxymethyl) alkanoate curcuminoid derivative MTH-3 on cell cycle arrest, apoptotic and autophagic pathway in triple-negative breast adenocarcinoma MDA-MB-231 cells: An in vitro study. Int J Oncol 52: 67-76, 2018.

29. Lu CC, Yang JS, Chiang JH, Hour MJ, Lin KL, Lee TH and Chung JG: Cell death caused by quinazolinone HMJ-38 challenge in oral carcinoma CAL 27 cells: Dissections of endoplasmic reticulum stress, mitochondrial dysfunction and tumor xenografts. Biochim Biophys Acta 1840: 2310-2320, 2014.

30. Chang HP, Lu CC, Chiang JH, Tsai FJ, Juan YN, Tsao JW, Chiu HY and Yang JS: Pterostilbene modulates the suppression of multidrug resistance protein 1 and triggers autophagic and apoptotic mechanisms in cisplatin-resistant human oral cancer CAR cells via AKT signaling. Int J Oncol: Mar 2, 2018 (Epub ahead of print).

31. Gelles JD and Chipuk JE: Robust high-throughput kinetic analysis of apoptosis with real-time high-content live-cell imaging. Cell Death Dis 7: e2493, 2016.

32. Chiang JH, Yang JS, Lu CC, Hour MJ, Chang SJ, Lee TH and Chung JG: Newly synthesized quinazolinone HMJ-38 suppresses angiogenetic responses and triggers human umbilical vein endothelial cell apoptosis through p53-modulated Fas/death receptor signaling. Toxicol Appl Pharmacol 269: 150-162, 2013.

33. Ma YS, Weng SW, Lin MW, Lu CC, Chiang JH, Yang JS, Lai KC, Lin JP, Tang NY, Lin JG, et al: Antitumor effects of emodin on LS1034 human colon cancer cells in vitro and in vivo: Roles of apoptotic cell death and LS1034 tumor xenografts model. Food Chem Toxicol 50: 1271-1278, 2012.

34. Lai KC, Huang AC, Hsu SC, Kuo CL, Yang JS, Wu SH and Chung JG: Benzyl isothiocyanate (BITC) inhibits migration and invasion of human colon cancer HT29 cells by inhibiting matrix metalloproteinase-2/-9 and urokinase plasminogen (uPA) through PKC and MAPK signaling pathway. J Agric Food Chem 58: 2935-2942, 2010.

35. Wu SH, Hang LW, Yang JS, Chen HY, Lin HY, Chiang JH, Lu CC, Yang JL, Lai TY, Ko YC and Chung JG: Curcumin induces apoptosis in human non-small cell lung cancer NCI-H460 cells through ER stress and caspase cascade- and mitochondria-dependent pathways. Anticancer Res 30: 2125-2133, 2010.

36. Lu CC, Yang JS, Chiang JH, Hour MJ, Lin KL, Lin JJ, Huang WW, Tsuzuki M, Lee TH and Chung JG: Novel quinazolinone MJ-29 triggers endoplasmic reticulum stress and intrinsic apoptosis in murine leukemia WEHI-3 cells and inhibits leukemic mice. PLoS One 7: e36831, 2012.

37. Dasari S and Tchounwou PB: Cisplatin in cancer therapy: Molecular mechanisms of action. Eur J Pharmacol 740: 364-378, 2014.

38. Glick JH, Zehngebot LM and Taylor SG IV: Chemotherapy for squamous cell carcinoma of the head and neck: A progress report. Am J Otolaryngol 1: 306-323, 1980. 
39. Gao Y and Liu D: The roles of excision repair cross-complementation group1 in objective response after cisplatin-based concurrent chemoradiotherapy and survival in head and neck cancers: A systematic review and meta-analysis. Oral Oncol 51: 570-577, 2015.

40. Chiu YJ, Yang JS, Hsu HS, Tsai CH and Ma H: Adipose-derived stem cell conditioned medium attenuates cisplatin-triggered apoptosis in tongue squamous cell carcinoma. Oncol Rep 39: 651-658, 2018

41. Hsieh MT, Chen HP, Lu CC, Chiang JH, Wu TS, Kuo DH, Huang LJ, Kuo SC and Yang JS: The novel pterostilbene derivative ANK-199 induces autophagic cell death through regulating PI3 kinase class III/beclin 1/Atg-related proteins in cisplatin-resistant CAR human oral cancer cells. Int J Oncol 45 : 782-794, 2014

42. Zhu Z, Du S, Ding F, Guo S, Ying G and Yan Z: Ursolic acid attenuates temozolomide resistance in glioblastoma cells by downregulating $\mathrm{O}^{6}$-methylguanine-DNA methyltransferase (MGMT) expression. Am J Transl Res 8: 3299-3308, 2016

43. Li J, Liang $X$ and Yang X: Ursolic acid inhibits growth and induces apoptosis in gemcitabine-resistant human pancreatic cancer via the JNK and PI3K/Akt/NF- $\kappa$ B pathways. Oncol Rep 28: 501-510, 2012.

44. Shan JZ, Xuan YY, Ruan SQ and Sun M: Proliferation-inhibiting and apoptosis-inducing effects of ursolic acid and oleanolic acid on multi-drug resistance cancer cells in vitro. Chin J Integr Med 17: 607-611, 2011.

45. Yang L, Liu X, Lu Z, Yuet-Wa Chan J, Zhou L, Fung KP, Wu P and Wu S: Ursolic acid induces doxorubicin-resistant HepG2 cell death via the release of apoptosis-inducing factor. Cancer Lett 298: 128-138, 2010.

46. Wang J, Liu L, Qiu H, Zhang X, Guo W, Chen W, Tian Y, $\mathrm{Fu} \mathrm{L}$, Shi D, Cheng J, et al: Ursolic acid simultaneously targets multiple signaling pathways to suppress proliferation and induce apoptosis in colon cancer cells. PLoS One 8: e63872, 2013.

47. Gao N, Cheng S, Budhraja A, Gao Z, Chen J, Liu EH, Huang C, Chen D, Yang Z, Liu Q, et al: Ursolic acid induces apoptosis in human leukaemia cells and exhibits anti-leukaemic activity in nude mice through the PKB pathway. Br J Pharmacol 165 : 1813-1826, 2012

48. Yang G, Yang T, Zhang W, Lu M, Ma X and Xiang G: In vitro and in vivo antitumor effects of folate-targeted ursolic acid stealth liposome. J Agric Food Chem 62: 2207-2215, 2014.

49. Subbaramaiah K, Michaluart P, Sporn MB and Dannenberg AJ: Ursolic acid inhibits cyclooxygenase-2 transcription in human mammary epithelial cells. Cancer Res 60: 2399-2404, 2000.

50. Bui NL, Pandey V, Zhu T, Ma L, Basappa and Lobie PE: Bad phosphorylation as a target of inhibition in oncology. Cancer Lett 415: 177-186, 2018.
51. Cook SJ, Stuart K, Gilley R and Sale MJ: Control of cell death and mitochondrial fission by ERK1/2 MAP kinase signalling. FEBS J 284: 4177-4195, 2017

52. Datta SR, Dudek H, Tao X, Masters S, Fu H, Gotoh Y and Greenberg ME: Akt phosphorylation of BAD couples survival signals to the cell-intrinsic death machinery. Cell 91: 231-241, 1997.

53. Pareja F, Macleod D, Shu C, Crary JF, Canoll PD, Ross AH and Siegelin MD: PI3K and Bcl-2 inhibition primes glioblastoma cells to apoptosis through downregulation of Mcl-1 and Phospho-BAD. Mol Cancer Res 12: 987-1001, 2014.

54. Pereira JK, Machado-Neto JA, Lopes MR, Morini BC, Traina F, Costa FF, Saad ST and Favaro P: Molecular effects of the phosphatidylinositol-3-kinase inhibitor NVP-BKM120 on $\mathrm{T}$ and B-cell acute lymphoblastic leukaemia. Eur J Cancer 51: 2076-2085, 2015.

55. Lin Z, Jiang $\mathrm{J}$ and Liu XS: Ursolic acid-mediated apoptosis of K562 cells involves Stat5/Akt pathway inhibition through the induction of Gfi-1. Sci Rep 6: 33358, 2016.

56. Wu B, Wang X, Chi ZF, Hu R, Zhang R, Yang W and Liu ZG: Ursolic acid-induced apoptosis in K562 cells involving upregulation of PTEN gene expression and inactivation of the PI3K/Akt pathway. Arch Pharm Res 35: 543-548, 2012.

57. Lin J, Chen Y, Wei L, Shen A, Sferra TJ, Hong Z and Peng J: Ursolic acid promotes colorectal cancer cell apoptosis and inhibits cell proliferation via modulation of multiple signaling pathways. Int J Oncol 43: 1235-1243, 2013.

58. Gai L, Cai N, Wang L, Xu X and Kong X: Ursolic acid induces apoptosis via Akt/NF- $\mathrm{kB}$ signaling suppression in T24 human bladder cancer cells. Mol Med Rep 7: 1673-1677, 2013.

59. Zhang Y, Kong C, Zeng Y, Wang L, Li Z, Wang H, Xu C and Sun Y: Ursolic acid induces PC-3 cell apoptosis via activation of JNK and inhibition of Akt pathways in vitro. Mol Carcinog 49: 374-385, 2010.

60. Meng Y, Lin ZM, Ge N, Zhang DL, Huang J and Kong F: Ursolic acid induces apoptosis of prostate cancer cells via the PI3K/Akt/mTOR pathway. Am J Chin Med 43: 1471-1486, 2015.

61. Chuang WL, Lin PY, Lin HC and Chen YL: The apoptotic effect of ursolic acid on SK-Hep-1 cells is regulated by the PI3K/Akt, p38 and JNK MAPK signaling pathways. Molecules 21: 460, 2016.

62. Son HS, Kwon HY, Sohn EJ, Lee JH, Woo HJ, Yun M, Kim SH and Kim YC: Activation of AMP-activated protein kinase and phosphorylation of glycogen synthase kinase $3 \beta$ mediate ursolic acid induced apoptosis in HepG2 liver cancer cells. Phytother Res 27: 1714-1722, 2013. 